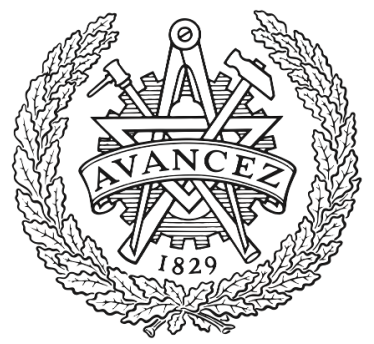

CHALMERS

UNIVERSITY OF TECHNOLOGY

\title{
The public and its assets: Performing appraisal and advocacy for blue and green infrastructure in London
}

Downloaded from: https://research.chalmers.se, 2023-04-26 12:13 UTC

Citation for the original published paper (version of record):

Peters, H., Landström, C. (2021). The public and its assets: Performing appraisal and advocacy for blue and green infrastructure in London. Environment and Planning E: Nature and Space, In press. http://dx.doi.org/10.1177/25148486211049912

N.B. When citing this work, cite the original published paper. 


\title{
The public and its assets: Performing appraisal and advocacy for blue and green infrastructure in London, England
}

EPE: Nature and Space

(C) The Author(s) 2021

(c) (i)

Article reuse guidelines: sagepub.com/journals-permissions DOI: I0.1 |77/25 |484862 I I0499I2 journals.sagepub.com/home/ene (S)SAGE

\author{
Helge Peters \\ University of Oxford, UK
}

\section{Catharina Landström}

University of Oxford, UK; Chalmers University of Technology, Sweden

\begin{abstract}
London's water sector professionals seek to secure public funds for blue and green infrastructure projects while also engaging with local advocates for river improvement. This paper argues that current project appraisal practice forms a barrier to aligning public investment with local demand because justifying investment requires the enactment of a utilitarian public good that is at odds with the noninstrumental values motivating local advocacy. Drawing on qualitative evidence and performativity theory, we show how the appraisal practices of water sector professionals and the environmental advocacy of London residents both enact publics in different arenas of water management: appraisal enacts a general public to secure funding, while advocacy enacts a particular public that serves to articulate local demand for environmental improvement. Whereas the performativity of a general public works through demonstrating nature's economic value to people, the performativity of local publics is animated by people's responsibility towards nature. We find that the general public that is enacted through cost-benefit analysis legitimizes public expenditure on readily demonstrable economic benefits, such as flood risk mitigation, while withholding funds from the water quality improvement valued by local publics. Comparing the performativities of general and local publics, we discuss the conditions under which appraisal and advocacy practices enact their respective underlying values. We conclude that the current appraisal practice frustrates the delivery of blue and green infrastructure projects that would respond to local demand for improving rivers.
\end{abstract}

\section{Keywords}

Cost-benefit analysis, local governance, London, water, publics

\section{Corresponding author:}

Helge Peters, School of Geography and the Environment, University of Oxford, Oxford, UK.

Email: helge.peters@ouce.ox.ac.uk 


\section{Introduction}

In England, regulatory guidance encourages water sector professionals to engage the public through research and outreach (Defra, 2013; Ofwat, 2016). At the same time, geographers work towards introducing notions of multiple publics and value pluralism to the water sector (Eden, 2017; Sharp, 2017). Yet practitioners contend with the persistent hold which the singular public as a product of economic calculation exerts over applied water management. In this paper we examine how water sector professionals and London residents perform publics through practices of appraisal and advocacy, respectively. We argue that the performativity of publics gives effect to conflicting values with respect to the natural environment, which forms a barrier to matching public investment into blue and green infrastructure (henceforth BGI) with local demand, particularly with respect to the improvement of surface water quality. This conflict principally follows from the dominance of cost-benefit analysis in UK public administration, which works against achieving value pluralism in hydro-social water management (Linton, 2014).

The practice of appraising the cost and benefit of public investment for water management gains relevance within a national context characterized by (a) surface water quality becoming an increasingly salient environmental problem recognized in UK media reports and regulatory assessments (Laville, 2020; Salvidge, 2020; Webster, 2020); (b) urban watercourses being reconsidered as vital elements of BGI, which comprises a planned system of surface water, drainage, and green spaces (Fairbrass et al., 2018) believed to deliver ecosystem services contributing to natural capital (Helm, 2015); and c) an emerging debate about the limits of narrowly conceived economic value as sole measure of the expediency of public expenditure (Mazzucato et al., 2020).

Within this context, our study finds that water sector professionals perform a general public through appraisal practices, which include environmental valuation for cost-benefit analysis. However, enacting a general public in the terms of welfare economics gives effect to utilitarian values that contradict the non-instrumental values animating local environmental advocacy. In contrast, we find that London residents perform local environmental publics through advocacy for river improvement across the arenas of urban regeneration, river daylighting, and rewilding. We argue that material consequences follow from this mismatch between different enactments of general and local publics: while local environmental publics create demand for BGI investment when advocating for water quality improvement on the grounds of human responsibility for nature, an economic notion of the general public steers BGI investment towards projects that demonstrate nature's benefit to people, such as flood risk mitigation and amenity. We find that some water sector professionals attempt to work around this mismatch by tactically foregrounding economically salient benefits rather than water quality improvement when raising funds.

This paper contributes a performative conceptualisation (Butler, 2010) of publics to the social studies of water management (Agarwal et al., 2000; Linton, 2014; Sharp, 2017). Performing the public serves to legitimize action in democratic polities (Dewey, 1927; Marres, 2007), including the mobilization of societal resources for conservation and environmental improvement. Our conceptualization of enacted publics that give effect to notions of the public good serves two analytical ends: rendering different publics and their values comparable, and illuminating the contextual factors shaping which public and whose values succeed in mobilizing resources. We find that the enactment of a general public responds to an institutional requirement to justify public expenditure by conducting cost-benefit analysis. We further suggest that current appraisal practice prevents water sector professionals from effectively engaging local residents concerned with surface water quality: cost-benefit 
analysis renders the non-instrumental values that move local residents to advocate on behalf of the natural environment illegible to the institutions that command societal resources. Nevertheless, we contend that recognizing multiple ways of valuing nature remains of practical importance to public participation in water management because non-instrumental values animate residents to advocate for the water environment, participate in planning, and demand public expenditure.

In what follows we briefly survey literature on the performativity of publics in order to draw a conceptual distinction between particular and general publics that will guide our empirical analysis (cf. Michael, 2009). There follows a brief contextualization of our case study and explication of our methods. The remainder of the paper documents different enactments of general and local publics by technical experts and London residents, respectively, across different arenas of water management. We discuss our empirical findings about performative publics in urban water management with a view to characterizing their pragmatic and substantive differences. We conclude by relating our main argument to concerns with value pluralism in BGI planning.

\section{Performing publics in hydro-social water management}

Democratic polities draw legitimacy from invoking the interest of the public (Dewey, 1927). The public does not pre-exist its invocation, but rather needs to be 'constructed through dialogue and action' (Staeheli et al., 2009: 634). The term public has a double meaning: in a political register, the public is an imagined social totality conferring legitimacy on collective action; in a theatrical sense, the public is a collective created through the performance of speech and action before an audience assembled in some arena (Warner, 2002). Considering the social effects of speech acts, performativity theory (Butler, 2019) offers a conceptual framework for drawing these two senses of the public together. As a social kind, the public is performed in the sense that actors convene a collective and assert its shared values in a way that is recognized by others as legitimately grounding socially binding action. A broad range of speech acts can have performative effects, including formal economic calculation (e.g. Mackenzie, 2006) and advocacy on behalf of the natural environment (Eden, 2017). In what follows we will discuss literatures on economic performativity and environmental publics in order to sketch a framework for understanding both the appraisal practices of welfare economics and the advocacy practices of environmental stewardship as different ways of performing the public in hydro-social water management.

The performative turn in economic sociology focusses on the work that economic theories, models, and various calculative devices do for constituting empirical economic phenomena such as markets and economic agents (Callon, 2007; Mackenzie, 2009). A performative perspective on the theories and tools of economics brings into view how economics 'performs, shapes, and formats the economy' (Callon, 1998: 2) rather than representing some external economic reality. Geographers have studied development economics as a 'self-realization of economic knowledge' (Berndt and Boeckler, 2009), emphasizing how economic knowledge practices take on material force when put to work for the re-constitution of empirical economies in the global south. Such work suggests that welfare economics, too, functions as 'an engine, not a camera' (Mackenzie, 2006) when enacting its utilitarian values through cost-benefit analysis of public policy options.

Cost-benefit analysis requires input values for calculating the effects of policy on the public. Social studies of valuation investigate the performative work of bestowing economic value on something (Doganova et al. 2018). The monetary valuation of ecosystem services forms a routinized part of water management in England and Wales (Atkinson et al., 2018). However, environmental valuation methods such as stated preference surveys remain controversial, provoking 
critiques of their theoretical and methodological soundness and their propriety for supporting public decisions (Foster, 1997). Sociological observers of the political and juridical uses to which valuation surveys are put find their epistemic authority to be highly contingent on institutional context (Fourcade, 2011). Geographers query the constitutive role of such data practices for rendering nature valuable (Nost, 2015; Robertson, 2006). During valuation studies economists frequently survey households in order to generate data about their preferences. Tadaki et al. (2017) take issue with the way in which the economic precepts informing valuation survey design prescribe a utilitarian and instrumentalist idiom that constrains the range in which survey respondents can register their regard for the natural environment. In contrast, a performativity perspective brings the tools equipping economic data practices, such as the valuation survey, into view as enabling the enactment of a specifically economic version of the public good. From this vantage point, the constraints of valuation surveys are constitutive of utilitarian value by equipping participants with the calculative agency required to rank preferences concerning relative change in the natural environment (Callon, 1998). Aggregating these preferences, in turn, serves to enact a general public in economic terms.

Economic performativities of the public contend with environmental publics enacted in other practices. Eden (2017) theorizes collectives constituted in practical engagements with the natural environment as environmental publics. Materialist social studies of environmental politics emphasize the constitutive role of the natural environment in public life when actors make claims on account of being collectively affected by environmental matters (Braun and Whatmore, 2010; Marres, 2007). The concepts of Publics-in-Particular (PiP) and Public-in-General (PiG) introduced by Michael (2009) help distinguishing between different kinds of publics and illuminate their pragmatics. PiP are enacted on the basis of a shared condition, for example, exposure to a site of environmental pollution, which authorizes the claims of the PiP as authentic expressions precisely because of their particularity. Specific to place and materiality, the PiP bears conceptual similarity to the local environmental public theorized by Eden (2017) or the issue public by Marres (2007). In contrast, calculative practices such as cost-benefit analysis enact a PiG standing in for a social totality. ${ }^{1}$ Frequently the work product of credentialled experts, the PiG serves to anchor the political authority of administrative action in the epistemic authority of science. Cultural acceptance of the objectivity of formal numerical representation renders the PiG a valuable rhetorical resource within public controversies characterized by low levels of trust (Porter, 1995). However, the policy and technoscientific elites enacting the public as an aggregate of individuals are frequently challenged by competing performativities of the public as an affected collective (Wynne, 1996). Whereas Michael (2009) is primarily concerned with distinguishing different kinds of publics as they are invoked in public controversies about technoscientific issues, the remainder of this paper builds on his helpful distinction in order to trace the misalignment between different performativities of the public good in hydro-social water management.

\section{Researching economic and environmental performativity}

The empirical material drawn on in this paper was gathered as part of a large, interdisciplinary project exploring ways to improve integrated urban water management in London. One objective of this project was to develop participatory techniques for empowering local communities to have a say in water management decisions that require highly specialized technical expertise. In this context, we conducted a multi-sited qualitative investigation (Marcus, 1995) into local water management across three London boroughs from which BGI emerged as traversing multiple arenas and practices, including appraisal by technical experts as well as advocacy by local residents. As a consequence, our qualitative study focused on interviewing and observing the practices of technical experts and local residents as participants in BGI planning. 
Principal methods comprised in-depth interviews, ethnographic engagements, and the study of documents and software tools. Of a total of 21 in-depth interviews, 5 were with technical experts working for local government, consultancies or charities. Ranging from $45 \mathrm{~min}$ to $2.5 \mathrm{~h}$ in duration, interviews were conducted with a thematic interview guide, digitally recorded, and professionally transcribed. The interview transcripts were independently coded and analysed by the two authors, who then compared their interpretations (cf. Cloke et al., 2004). Studying performative practices requires analysing interviewees' accounts for their pragmatic dimension, including the situatedness of a practice-in-action in a wider socio-material network and the potential failure of a performative practice (Fox and Alldred, 2014). In the case of economic performativities such as project appraisal, this analytical strategy required starting with the economic practice and then tracing the sociotechnical networks that made it work or fail (Pellandini-Simányi, 2016). For instance, one interviewee voiced his frustration about an appraisal software's failure to adequately calculate the value of water quality benefits despite his conviction that the tool was based on the best available academic research. His account prompted us to conduct a qualitative critical analysis of software documentation and documents on cost-benefit analysis applied in surface water management, thus explicating the theoretical hinterland (cf. Law, 2004) of appraisal practices.

Across three London boroughs, we interviewed 16 members of Friends of parks groups, volunteers working with rivers trusts, and members of residents' associations. These collectives are understood as 'environmental stewardship groups', that is, people joining together to engage with local environmental issues (Peçanha Enqvist et al., 2018). Stewardship groups are involved with the management of, education about, and advocacy for local environments, often with emphasis on one of these activities (Enqvist et al., 2019). The groups differ with regard to motivations and objectives. ${ }^{2}$ Since there is no register of local volunteer-based stewardship groups we used snowball sampling to recruit interviewees (Noy, 2008). Participants were mostly interviewed on-site, for example, in the vicinity of the local river or park that were their focus of interest ${ }^{3}$

Formal interviews were complemented by informal conversations with the attendants of consultations, community meetings, and public engagement events involving both technical experts and environmental stewardship groups. Taking part in these activities provided ethnographic insight complementing the understanding gained through interviews. Field notes enabled interpretation of this version of multi-sited event ethnography (Baird, 2017). The document study included limited print and unpublished texts held in local libraries and archives. In addition, we read nonacademic print and on-line writing on various aspects of applied water management as well as community-created media. Qualitative interpretation of this material provided in-depth understanding of the local context for water management in London (cf. Bowen, 2009).

\section{Estimating the benefits of London's BGI}

Surface water management in London confronts the combined challenges of stormwater drainage in a changing climate, diffuse pollution from road-runoff, urban growth as well as heightened concern for environmental quality - all set in the context of an ageing water and sewerage infrastructure. Urban planners have responded to these challenges with nature-based solutions, which form part of the wider BGI that supports urban life (Fairbrass et al., 2018). One example for nature-based solutions are sustainable drainage systems (henceforth, SuDS). SuDS comprise a range of local, often small-scale, interventions into the built environment, which can take the form of raingardens, bioswales or constructed wetlands (Fletcher et al., 2015). Typically, SuDS are held to realize multiple co-benefits in addition to their function for surface water management, such as preserving biodiversity, providing amenity, contributing to health and well-being, and storing carbon (SusDrain, 2020b). 
Estimating the costs and benefits of SuDS projects is the job of technical experts. These include engineers employed by local authorities as well as other formally credentialled water sector professionals working for utilities, consultancies or charities. Technical experts have a key role in BGI planning because their work of demonstrating the benefits of SuDS secures resources from funders that are necessary to implement projects which respond to local demand for environmental improvement. Technical experts move between the arenas of water management that we examine in this paper: principally tasked with the technical work of planning and appraisal, their public engagement work also exposes them to the advocacy of local residents. The local scale of SuDS accords residents of a neighbourhood an important role in their planning and implementation (Carriquiry et al., 2020). SuDS such as constructed wetlands can inspire local advocacy for environmental improvement. Technical experts involved in BGI planning work under policies encouraging public engagement, which means that they frequently interact with residents during consultations and outreach events. On the occasion of these engagements, technical experts learn about the values motivating local residents to advocate for environmental improvement, which frequently include non-instrumental values of responsibility towards nature.

However welcome local advocacy for SuDS may be to planners, public investment into BGI still requires formal project appraisal. The purpose of project appraisal is the production of evidence that SuDS projects contribute to the economic objectives prioritized by funders such as local authorities or national government programmes (Dobson and Dempsey, 2021; Finewood et al., 2019; Horwood, 2011). In the UK there exists a norm in public administration that requires project assessment using tools set out in formal HM Treasury guidance, which considers cost-benefit analysis as the gold standard for demonstrating public value (Atkinson et al., 2018; Mazzucato et al., 2020).

Estimating the costs and benefits of SuDS while also engaging local residents, technical experts negotiate a mismatch between the economic benefit to the general public, which justifies investment to purse holders, and the non-instrumental values animating local publics to demand investment. In the following sections, we turn to examining how technical experts enact a general public through appraisal practices, which include figuring rivers as assets (4.1), complying with an institutional norm for justifying expenditure (4.2), and calculating the benefits of SuDS with the help of BGI planning software (4.3).

\section{Appraisal I: Turning rivers into assets}

When technical experts talk about SuDS and BGI, they frequently figure them as assets. An economic metaphor borrowed from the discourse of financial economics, the asset denotes anything from which a recurring income stream can be expected (Muniesa et al., 2017). When talking about BGI as assets, the technical experts we interviewed blended economic concepts with consideration of the values which local residents bestow upon urban nature. For instance, a PhD-level environmental scientist working for a wildlife charity, who is responsible for public engagement with urban water monitoring and improvement projects, argued for the importance of restoring access to urban rivers on the grounds that 'a river that is accessible and enjoyed and used and cherished by its community is one that is invested in as an important asset and nurtured'. Prompted to explain his choice of words, which interlaces the languages of finance and care, the scientist reflected on the divide between expert and lay discourses:

Yes, it's sort of economic, finance and I suppose it's being impacted by this notion of natural capital and ecosystem services where we have to quantify their value and it's very hard, isn't it, to value it. Maybe asset is the wrong word and I'm sure lots of people in the community don't view it as an asset. They view it as something they'd have to cross or something where mosquitoes live. 
Such talk about BGI as assets is indicative of the firm embeddedness of the natural capital approach and its utilitarian precept of environmental valuation in UK public policy. The natural capital approach regards BGI as capital assets from which economic benefits flow (Helm, 2015). The environmental valuation practices underlying natural capital accounting have been characterized as enacting instrumentalist and anthropocentric relationships towards non-human nature (Barua, 2019; Battistoni, 2017). However, the conceptual distinction between instrumentalist and other values remains ambiguous in applied environmental management (Tadaki et al., 2017). For instance, a municipal drainage engineer, who frequently engages local publics during planning consultations, imagined wetlands as assets whose multiple capacities exceed a narrowly instrumentalist framing of value:

Where we've created a wetland, we've actually created an asset that reduces flooding and cleans water and provides biodiversity, but it is actually a valuable asset in its own right. It's a place where people can see water and experience water and see the wildlife and actually care about it.

Here, the instrumental value of SuDS is imagined as benefits pertaining to flood risk mitigation, biodiversity, and water quality; ecosystem services which can be formally attributed to a wetland as a natural capital asset. Yet the engineer also acknowledges a kind of value of the wetland which exceeds formal accounting, residing instead in its capacity to foster experiential practices and relationships of care with urban nature.

As technical experts talk about BGI as assets, their discourse blends the natural capital approach with the non-instrumental values which members of environmental stewardship groups voice when engaging with water sector professionals. Assembling a business case in order to persuade purse holders to fund a sustainable drainage scheme, technical experts resolve such ambiguities of value in favour of a formal calculation of return on investment into an asset. In what follows we discuss how the institutional context of public administration requires cost-benefit modelling in order to enact BGI as an asset worthy of public investment.

\section{Appraisal II: Justifying investment}

Anchored in the regulatory framework governing privatized water utilities in the UK, the economics discipline enjoys a privileged claim to represent the public good in English and Welsh water governance. ${ }^{5}$ Decision-makers gauge the public good from the result of environmental cost-benefit analysis, which estimates the economic value that society as a whole derives from changing the natural environment (Sen, 2000; Sunstein, 2005), and which in turn is enabled by accounting for the natural environment as natural capital assets (Helm, 2015). A central decision-support method, cost-benefit analysis shapes UK water science and management through its rigid formal requirements (Lane et al., 2011). In England, formal economic modelling of costs and benefits is a part of the business case prepared by water sector professionals when attempting to persuade purse holders to release funds for BGI improvement.

There exist specific historical reasons for the prevalence of cost-benefit analysis as a technique for legitimating decisions in UK public administration, which is further reinforced through official guidance documents. Initially met with controversy (Adams, 1971), cost-benefit analysis eventually came to enjoy currency as the 'best game in town' (Pearce, 1998: 97) in British environmental governance. From a practitioner perspective, Grove-White (1997) explains the rise of environmental valuation and cost-benefit analysis during the Thatcher administration as a result of attempts to elevate the status of environmental policy in the face of Treasury adversity to the use of public funds for conservation action. ${ }^{6}$ This explanation concurs with scholarship investigating cost-benefit analysis as a technique for creating 'a basis for mutual accommodation' between technical experts 
and public office holders in the absence of trust (Porter, 1995: 149). As it stands, comprehensive HM Treasury guidance on the appraisal of policies, programmes, and projects in the form of the Green Book is indicative of a 'national policy culture' (Atkinson et al., 2018: 113) where civil servants as well as companies dealing with the government are required or consider it prudent to engage in environmental valuation in order to assess costs and benefits of proposed actions.

As a variant of economic modelling, cost-benefit analysis belongs to the domain of welfare economics. Welfare economics is concerned with analysing the economic effects of policy on the welfare of the general public with a view to rationalizing policy decisions. Welfare is conceived in utilitarian terms and the public as a social totality modelled as an aggregate of households (Sen, 2000). An axiomatic assumption of cost-benefit analysis states that there is no social entity over and above the individual, so that "society" is always the aggregation of individuals' (Pearce, 1998: 87). ${ }^{7}$ Modelling the welfare effects of environmental policy actions requires input values about the utility which individual households derive, for example, from improving a river ecosystem. These input values are the product of accounting practices valuing environmental goods in monetary terms. However, monetary valuation is difficult to do for environmental goods without observable prices, requiring valuation by proxy or value elicitation by laboriously surveying households. Recent years have seen efforts to streamline cost-benefit analysis by developing software tools using standardized input values that are partly derived from prior household surveys (Atkinson et al., 2018: 114). In the next section we look at such a tool used for BGI appraisal and examine the performative effects of the contingent valuation method that produced its input values.

\section{Appraisal III: The BEST public}

The Benefits Estimation Tool (promoted under the acronym B£ST) helps calculating whether the benefits derived from sustainable drainage schemes exceed the cost of their construction. The software tool not only outputs a cost-benefit ratio, but also incorporates a capital budgeting model, which accounts for benefits flowing from ecosystem services akin to income streams from financial assets (Muniesa et al., 2017). Made available for free download by the UK Construction Industry Research and Information Association, the tool consists of an elaborate spreadsheet, estimating in monetary terms the benefits derived from 15 different ecosystem services connected to a sustainable drainage scheme (Horton et al., 2019). According to its developers, the B£ST software has been downloaded about 10,000 times and is used widely in UK local government (Shaffer, 2020).

B£ST incorporates sharable values derived from the National Water Environment Benefits Survey (NWEBS). Funded by the UK Department for Environment, Food and Rural Affairs, NWEBS is based on a large-scale willingness-to-pay survey covering England and Wales, which initially had been commissioned in 2007 and subsequently was updated by Metcalfe et al. (2012). Asking participants to disclose how much they would pay for seeing a change in the water environment, this survey falls into the category of stated preference or contingent valuation methods. Economists deploy these methods because the ecological quality of a river is not traded on a market and therefore its price cannot be observed as an indicator of the utility a buyer would derive from changing river quality. Rather than observing market prices, then, economists elicit utility with the help of household surveys. With the aid of a questionnaire, Metcalfe et al. (2012) staged a tightly scripted interaction between survey respondents and researchers in which individual respondents were invited to calculate and record monetary values for a set of preferences regarding changes in the water environment. Based on the results, the Environment Agency circulates input values for the monetary benefit which households in England and Wales are held to derive from improving the ecological quality of rivers (Palmer and Haigh, 2013). 
Rather than inviting narrative or otherwise unstructured expression of the various ways in which survey participants might regard the natural environment, the design of the survey instrument equipped participants with the calculative capacity to enact the value of the water environment in accordance with the expectations of economic theory (Callon, 2007; Mackenzie, 2009). The survey instrument asked study participants to consider a series of cards: quality level cards described three different levels of environmental quality as high, medium, and low. Each level had been elaborated with three bullet points enumerating (1) the presence of plant and animal life, (2) the visual impression of the water and (3) its suitability for contact activities (Figure 1).

A further card presented participants with maps charting the proportion of high, medium, and low-quality bodies of water in their local environment as a 30-mile radius as well as nationally ${ }^{8}$. Finally, willingness-to-pay cards asked participants to consider a set of pie charts representing future changes to the proportion of high, medium, and low-quality water bodies in their local and national environment under certain options (Figure 2).

A no-change option required no monetary commitment. Change options required the participants to either record on the card the annual amount they would be willing to add to their water bill, or record their consent to prescribed annual payments of twenty or thirty pounds. Participants were asked to make 'real choices', that is, to account for opportunity costs by considering their household budget and 'the things that you and your household need or would prefer to spend your money on before you decide' (Metcalfe et al., 2012: 13).

The survey instrument equips the calculative agency (Callon, 1998) of participants by enumerating a finite set of possible changes to the state of the environment, which allows ranking them according to preference, and subsequently considering the cost of the preferred change. Strictly limiting the expression of value to a magnitude of preference (Tadaki et al., 2017), the survey instrument neither prompted nor recorded narrative accounts of the diverse ways in which changes to ecological quality might matter to participants. Through its rigid structuring of the informational environment participants were presented with, the survey design created a 'space of calculability' (Callon, 1998: 191) that enabled participants to value nature in the way economic theory would expect from a rational economic agent.

Subsequent aggregation of the individual values elicited during the survey enables the calculation of the total benefit, in monetary terms, which the public derives from investing in the

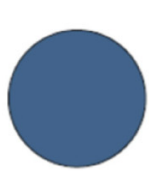

Dark Blue - quality is "High".

- There will be a diverse and natural range of plants, insects, fish, birds and other animals.

- Water will generally have the right degree of clarity and there will be no noticeable pollution.

- Water will generally be suitable for contact activities, such as rowing or wind surfing.

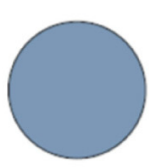

Mid-Blue - quality is "Medium".

- There will be plants, insects, fish, birds and other animals, but there will be some fish and other wildlife missing.

- Water will be slightly murky or discoloured in parts, and there will sometimes be visible pollution in some places, and some algal blooms.

- Water will be suitable for contact activities in some areas but not others.

Light Blue - quality is "Low".

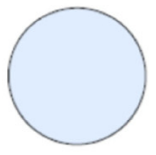

- There may be limited or no plants or wildlife, or the water may be dominated by a single plant species.

- Water will generally be murky or discoloured, and may sometimes be bad-smelling in some places. There may also regularly be visible pollution in some places, and frequent algal blooms.

- Water will be unsuitable for contact activities.

Figure I. Water quality information on the survey instrument. Facsimile from Metcalfe et al. (20I2). 
improvement of urban water quality. Incorporated into the cost-benefit analysis which technical experts conduct with the aid of the B£ST tool, the input values generated by the NWEBS survey give shape to the $\mathrm{PiG}$ as a statistical aggregate comprised of English and Welsh households that derive monetary value from investment into BGI. Insofar as the estimated value exceeds the cost of construction, this enactment of a utilitarian public good is capable of effecting socially binding consequences with respect to the investment decision of funders.

In contrast, the following section documents the performativity of local environmental publics that claim non-instrumentalist values.

\section{Local environmental publics in London}

In London, community groups frequently take on the responsibility of caring for a local river or green space. Interviewing members of such groups in Northeast, Northwest, and Southwest London we learned about how they enact publics that stress non-instrumental values with respect to the water environment alongside the benefits that BGI provides to people. London residents enact local environmental publics by engaging in urban planning consultations, rallying community members in response to pollution events, and publicizing their views in local circulars and on social media. Using these fora of public address, residents assemble local environmental publics (Eden, 2017) by drawing strangers into their discourse about environmental stewardship (Staeheli et al., 2009). Local publics tend to be enacted where environmental stewardship groups have previously been established. These groups meet regularly for guided educational river walks, monitoring pollution, or hands-on group activities including riverbank litter pickups and the removal of invasive flora such as Himalayan balsam. They share a highly site-specific focus, are made up of residents of a local area, and typically reference their borough or a local water course in their name. Collaboratively engaged in sustained environmental practice, they are 'environmental stewards', that is, 'civic groups that conserve, manage, monitor, advocate for, and educate about a wide range of quality of life issues' (Fisher et al., 2012: 28). Environmental stewardship groups tend to be

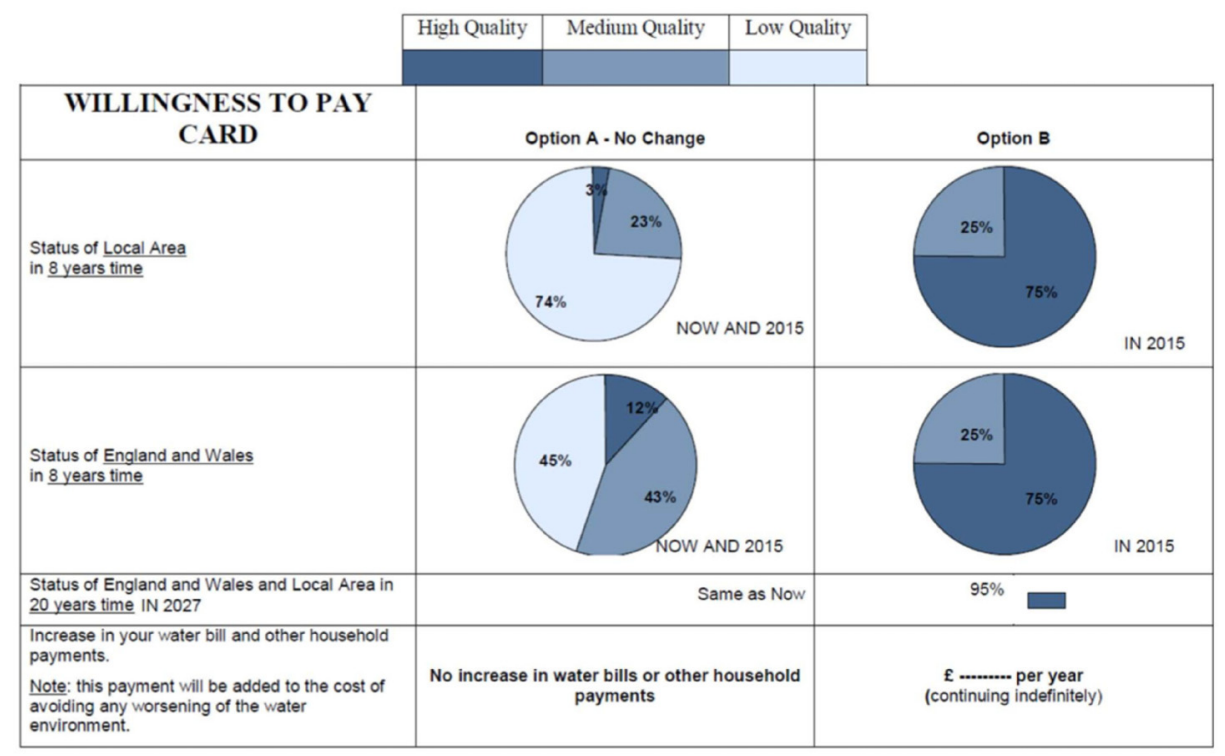

Figure 2. Willingness-to-pay card from the survey instrument. Facsimile from Metcalfe et al. (2012). 
actively involved in urban planning, can be called upon as stakeholders in consultations and community outreach efforts of local authorities and utilities, and occasionally advocate for nature-based solutions such as SuDS. ${ }^{9}$

Environmental stewardship groups differ with respect to their formal organization and the communities they work in. In Northeast London, we interviewed members of a group that was affiliated with a London-wide charity. Made up of a half dozen volunteers meeting regularly in a local public house, the group was co-chaired by a retired professional and a charity worker, who both lived in their own properties and organized hands-on volunteering and outreach activities such as litter picks and river walks. Interviewees from a different group in Northeast London worked towards creating and protecting urban nature as a communal space in the face of private development. In Northwest London, a river-focused group was unaffiliated with any larger organization but rather modelled itself on the 'Friends' groups that co-manage local green spaces across England. In a suburban commuter community constructed in the interwar period, this group convened neighbours with properties adjacent to a brook which they perceived as problematically polluted. Finally, the group in Southwest London was independent as well, but organized as a registered charity with a formal membership of several hundred members. Chaired by a retiree whose property overlooked a Thames tributary flowing through an affluent Green Belt community, this organization offered a broad range of outreach activities in addition to participating in formal planning consultations including for the nearby Heathrow airport expansion.

In what follows, we document how members of local environmental stewardship groups enact PiP (Michael, 2009) through practices of advocacy. Specifically, we will document the performativity of local environmental publics across the arenas of urban regeneration (5.1), river daylighting (5.2) and rewilding (5.3). As they advocate for rivers, local environmental publics articulate noninstrumental values with regard to the water environment. We will subsequently discuss how their values clash with the utilitarian public good that technical experts enact through cost-benefit analysis.

\section{Advocacy I: urban regeneration}

Participating in the urban planning process, members of some environmental stewardship groups enact publics by making representative claims (Saward, 2006) on behalf of future residents. Planned by the London borough of Enfield as lead developer, Meridian Water is a large-scale urban regeneration programme on a former industrial site at the confluence of two brooks emptying into the river Lea (Enfield Council, 2019). The master plan for the development boasts the creation of a 'new waterfront eco quarter' (Enfield Council, 2013: 8) comprising 10,000 new homes, promising that siting the development along the watercourses would help 'creating a more attractive living environment and supporting higher property values' (Enfield Council, 2013: 14).

Whereas the master plan promises increased access to urban water as a major driver of the future economic value of the properties under development, members of a local environmental stewardship group alerted the developer to the poor environmental quality of the brooks. In the opinion of one member, the promotional rhetoric of the developer did not match the reality on the ground because 'they hadn't really thought through what they would need to do ... to make sure that these streams didn't arrive highly polluted'. Another member imagined herself in the role of the developer when doubting the value of waterfront living that could be derived from the current state of the brooks, claiming that 'you don't want to be a developer building some lovely flats ... and you've got filthy stinking water and it is quite stinky actually'.

Agreeing that substantial environmental improvement work would likely need to be done, the developer invited members of the environmental stewardship group to a meeting intended to gauge the kind of urban water environment that future residents might value. As one of the 
environmentalists explained, the group perceived this invitation as an opportunity to promote what they valued about urban nature by making representative claims on behalf of future residents of the planned development:

[the environmental stewardship group] have tried to present themselves as the voice of the community before there's actually a community there. We've been trying to say, if we were that community, this is what we would like, so we have a use, I suppose, in being the voice of the citizen.

Members of the group managed to plausibly claim that future residents would value a water environment rich in biodiversity, necessitating physical interventions in the watercourses that would improve their ecological quality. Formulating a number of 'asks', the group proposed implementing sustainable drainage schemes such as the upstream construction of a series of urban wetlands that would prevent pollutants from entering the streams. In addition, the group negotiated that biodiversity should be improved by making parts of the stream inaccessible in order to provide wildlife habitat. As a result of the group's engagement, the developer agreed to consider adapting the design of the watercourses in order to accord with the values which the group had voiced on behalf of future residents. Consequent to their enactment of a public in the planning process, the group had claimed that future residents would share their own judgment with respect to the intrinsic value of improving ecological quality even if that meant making parts of the newly constructed water environment inaccessible to residents.

\section{Advocacy II: river daylighting}

Some members of local environmental stewardship groups seize on the material capacity of daylighted rivers to negatively affect residents' wellbeing in order to enact a local environmental public calling for the improvement of environmental quality. Daylighting is the practice of restoring rivers to the surface that previously had been banned into underground culverts (Wild et al., 2011). When carrying high levels of pollution, a daylighted river can provoke local residents to demand further improvement of the environmental quality of the newly surfaced water body. In such a case, the polluted river becomes politically constitutive through its material capacity to affect residents as a collective (Braun and Whatmore, 2010). Demanding redress from their local authority, residents enact a Public-in-Particular (Michael, 2009) in the sense of a public that is collectively implicated in the material issue (Marres, 2007) of surface water pollution.

The river Moselle serves as an illustrative case. Flowing through the London borough of Haringey, long stretches of the Moselle had been culverted beginning in the 19th century. A Council-led effort to restore a section of the river in an urban green space created roughly $400 \mathrm{~m}$ of meandering river set within a newly landscaped park featuring a pond, sloping banks, and floodplains crisscrossed by footpaths and three wooden bridges (Figure 3). However, resurfacing this section of the Moselle disclosed levels of pollution which local residents found unacceptable. Foul water misconnections led to the growth of sewage fungus and an odour that viscerally disturbed an otherwise pleasantly verdant impression of the landscape. On the day of a site visit, the smell of sewage lingered in the air, with a local patron of the park café remembering how 'it was revolting and made you feel slightly nauseous but now it isn't anywhere near as bad but it is still a bit pongy'. The carefully rewilded riparian environment of the Moselle was signposted with warnings against the hazard of physical contact with the water (Figure 4). Resurfacing the river had also surfaced extant pollution, which affected local resident's ability to enjoy the urban nature. Eventually investigations found that, in addition to private pipe misconnections, the sanitary installations of a local school had been misconnected, causing large amounts of raw sewage to pollute the river (Allin, 2019). In response, affected residents and the local Friends of the park group formed a 
forum concerned with the rivers of the borough which lobbied the local authority, statutory bodies, and water utility to investigate and clean up the daylighted Moselle.

Rather than discouraging further daylighting efforts, this prior experience with a public reaction to the underdelivery of environmental improvement motivated local residents to demand the deculverting of another section of the Moselle from a property developer in the suburban district of Wood Green. Both the developer and the local authority argued that the daylighting of the river at the site of the planned development would pose an unacceptable public health risk due to poor microbial water quality (Bell et al., 2019). In contrast, a member of a local environmental stewardship group involved in planning consultation argued on behalf of restoring the river to the surface:

It's not a helpful approach for the planning system to take that the quality of the water has to reach a certain level before you de-culvert or daylight because the whole point of this one in this park was, if we open this up, then there will be pressure to improve the water quality $[\ldots]$ the whole point is you open it up and then the debate happens because it's open.

Recalling the experience with daylighting the Moselle in the Lordship Rec urban park, this interviewee anticipated the way in which residents are likely to negotiate the under-delivery of environmental improvement at the site of the planned Wood Green development: forming ad hoc environmental publics when river restoration projects produce problematic urban natures, residents demand the improvement of surface water quality through public works.

The interviewee's account troubles a narrowly instrumentalist framing of the value of BGI that would see residents benefitting from the ecosystem services a daylighted Moselle might deliver. In the eyes of the interviewee, it is dissatisfaction with the disservice a daylighted river is liable to do to residents, rather than prospective benefit, which drives further environmental improvement efforts. When daylighted rivers turn out to smell of sewage, their water covered with unsightly fungus, then local residents experience BGI as a nuisance rather than as benefitting their wellbeing. Seizing on a problematic nature surfaced by river daylighting, local environmentalists enact a public that demands funds for further environmental improvement.

\section{Advocacy III: river rewilding}

Some members of environmental stewardship groups publicize their environmental values when promoting river rewilding in social media posts, podcasts, and newspaper op-eds. Using digital and print media as fora of public address, such media practices enact publics by drawing strangers into the environmentalist discourse of river rewilding (Staeheli et al., 2009). Rewilding incorporates a commitment to the autonomy of non-human nature, foregrounding the capacity of ecosystems to sustain themselves without human intervention as the restorative aim of conservation practice (Jørgensen, 2015; Lorimer et al., 2015; Prior and Ward, 2016). During interviews with members of environmental stewardship groups who actively produce media, these environmentalists emphasized their non-instrumentalist regard for rivers as places that offer habitat to wildlife and that should occasion responsible practices toward an autonomous nature holding intrinsic worth.

For instance, a retired engineer living in suburban North London published an op-ed in a borough circular that pleaded with homeowners to prevent pollution by checking for private pipe misconnections. A volunteer engaged in the restoration of a local brook, he described rewilding as a landscape intervention that would benefit wildlife through restoring human access to the watercourse. Whereas wilderness is traditionally imagined in the West as a space separate from society and devoid of human activity (Cronon, 1995), this volunteer imagined a rewilded river as inviting human activity. Restoring the brook meant to him re-engineering its course and the riparian zone in order to create 'a natural course of meanders and sloping sides'. Importantly, he sees 


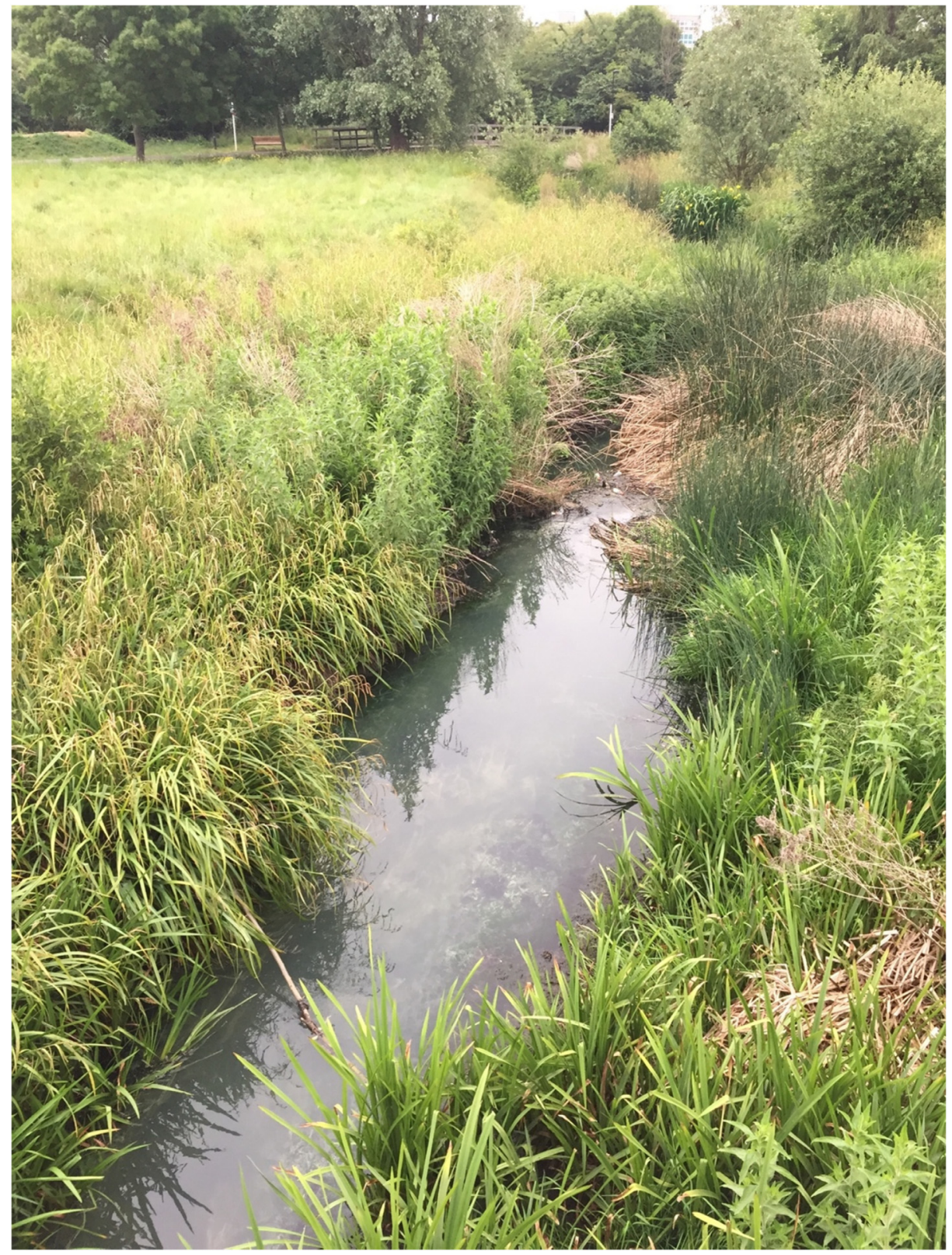

Figure 3. A section of the daylighted Moselle in a London park.

removing the concrete walls and fencing, which currently prevents access to parts of the brook, as a precondition for promoting responsible practices toward the natural environment because

If the river was more obvious, if it was rewilded and brought into the open, if people were encouraged to go paddling in it and see if there is any insect life in it and all the other things you do when you're a kid with rivers, then it would be more in people's consciousness and they wouldn't be so willing [to pollute] 


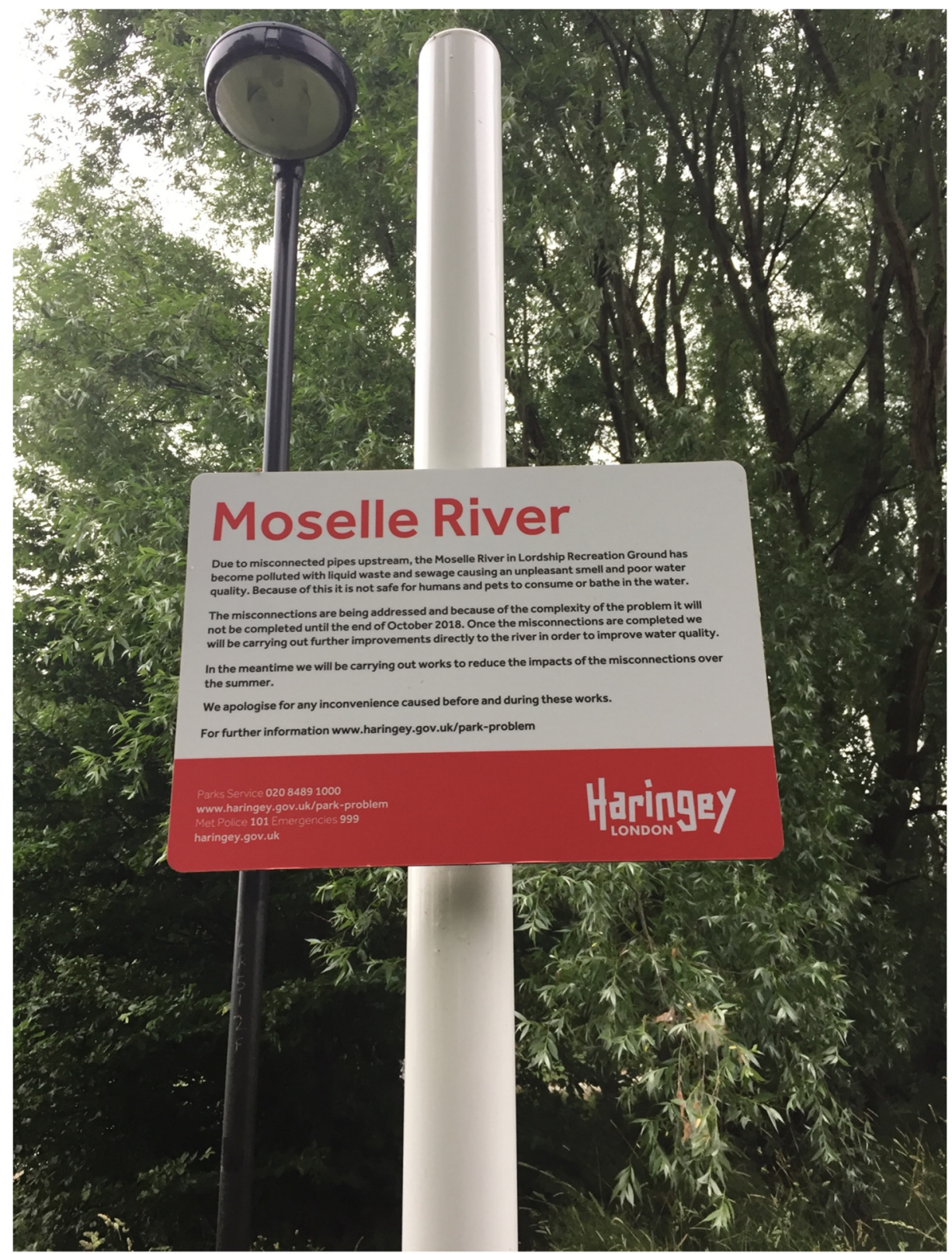

Figure 4. Safety warning posted by the local authority along the Moselle.

A similar sentiment was expressed by an interviewee campaigning on behalf of rewilding a different North London brook that empties into the river Lea. A co-convenor of a local environmental stewardship group, this environmentalist podcasted and regularly posted about the local water environment on social media platforms. Placing a high value on ecological quality and the presence of wildlife in the brook, she emphasized the autonomous capacities of non-human nature. As she pointed at the concrete canal within which the brook currently flows through a local public park, she 
argued that 'rivers try and cure themselves like everything in nature, they're always trying to work to restore themselves and we keep stopping them'. In her view, the public good would be best served by aiding the actualization of an autonomous potential of nature to heal itself from the human infractions of pollution and straitjacketing within concrete channels. Combined with the construction of wetlands, a rewilded river would be capable of "cleaning the water naturally, purely natural and no chemicals or barriers'. However, this interviewee was aware of the potential conflicts between her own and other residents' ideas about the public good with respect to rewilding. While walking through the park, she recounted conversations with local park users who had expressed 'shock' about the way in which the park had changed over their lifetime from 'all mown lawns and green space' toward a 'wilder' appearance. Against the background noise of a park-keeper mowing the lawn, she pointed at a part of the riverbank where neatly mown lawn turns into a section of tall grass adjacent to the canalized river, imagining herself persuading the park-keeper of 'leaving some [grass uncut] and bits can be accessible and then bits can be for wildlife'. Such remarks disclose river rewilding as reaching for a new distribution of urban space that would restore wildlife habitat as valuable in its own right.

Publicizing their views about river rewilding, members of environmental stewardship groups make a case for human responsibility towards the natural environment that is rooted in respect for its autonomy and intrinsic value. Such enactments of environmental publics serve to demonstrate local demand for projects that improve the ecological quality of London's rivers. Voicing their views while responding to pollution incidents, participating in urban planning, and creating media, members of environmental stewardship groups enact PiP (Michael, 2009). These publics render judgments of worth about the urban water environment that express their constituents' noninstrumental values with respect to nature.

\section{Must SuDS ride on PiGs? Matching investment with local demand}

In contrast to the non-instrumentalist values promoted by local environmental publics, the institutional context of public administration requires the demonstration of instrumental, economic benefits in order to justify expenditure on BGI. This results in a mismatch between the benefits driving investment into BGI and the kind of environmental improvement which local publics advocate. Consequently, technical experts face a challenge: tasked with delivering BGI projects that respond to local demand, technical experts have to resolve a mismatch between the local publics advocating for environmental improvement and the general public recognized by funders. Whereas the former locate the public good in the responsible stewardship of an intrinsically valuable nature, the latter require a quantification of nature's contribution to the public welfare. As a result, SuDs ride on PiGs. That is to say, technical experts have to enact a PiG when creating a business case designed to persuade a funding body to invest in SuDS.

Misalignment between different publics and their values links into a lack of funds for improving environmental quality. An article on SuDS by professional body Chartered Institute of Water and Environmental Management laments that 'funding gives priority to tackling flood risk over improving air and water quality' (CIWEM, 2020). A drainage engineer employed by a local authority concurs, pointing out how the water quality improvements demanded by local environmental publics can be difficult to justify with established appraisal practices:

You can't really monetize water quality at the moment. What is the value of a clean river? Because if you talk to members of the public, everyone agrees that rivers shouldn't have pollution in them, but it's crazy that you can't really get money. 
The lack of resources for improving surface water quality is exacerbated by the difficulty of demonstrating that the general public benefits in economic terms from the interventions which local publics desire. The drainage engineer recalled using the B£ST software to appraise several local SuDS projects with the result that the monetary value estimated for water quality benefits turned out to be negligible compared to the value of the benefits pertaining to flood risk mitigation, amenity value, and public health. A similar picture emerges from the project examples on the website promoting the software tool (SusDrain, 2020a).

Some technical experts have developed tactics for working around this misalignment. These tactics, too, turn on the performativity of the public good. While no less material in their effect of releasing funds, such performative practices are more consciously theatrical when technical experts stage some benefits of SuDS in the foreground while backgrounding others. Whereas advocates of SuDS stress their multiple benefits (SusDrain, 2020b), in practice their development tends to be led by a primary benefit. Appraising BGI projects, technical experts have to weigh public demand for water quality improvement against the multiple policy agendas of different funders and select which demonstrable benefits should drive project implementation (cf. Dobson and Dempsey, 2021; Horwood, 2011; Willems et al., 2021). Rather than directly responding to the demands of a local public, the primary benefit leading SuDS development depends on appraisal practices that match the evaluative metrics of different available funding streams with the calculative capacities of tools such as the B£ST software.

As a result, technical experts tactically emphasize the multiple co-benefits of projects to different funders. As the municipal engineer put it, when assembling different grants in order to match the sum needed for realizing a SuDS project 'you've got to be a bit of a salesman'. A report summarizing 20 years of river restoration work in Greater London echoes our interviewee. Lamenting the 'difficulty in aligning funding streams to deliver multi-benefit projects', the report subsequently details the practice of dividing project goals into primary objectives, which can be explicitly quantified and demonstrated to funders, and secondary objectives, which 'incorporate anticipated benefits supported by local knowledge but are not usually as easily quantified as primary objectives' (Webb et al., 2020). When SuDS ride on PiGs, salient economic benefits such as flood risk mitigation and amenity are foregrounded while the surface water quality improvement advocated by local publics remains off-stage.

\section{Discussion}

Our findings suggest that water sector professionals respond to local demand for improving water quality by constructing a general public in economic terms in order to secure resources for SuDS. Securing funds pivots on the ability of technical experts to enact a PiG which demonstrably benefits from investment into BGI. When the values of local publics prove incommensurable with the economic benefit to the general public, technical experts solve this problem by selecting economically salient benefits for demonstration.

Local and general publics can be compared as performative effects: both advocacy and appraisal involve speech acts with potentially binding consequences for others (Butler, 2019). While advocacy practices are capable of successfully enacting their version of the public good in the water management arenas of urban regeneration, daylighting, and rewilding, the arena of public investment requires enacting a different public good with different means, namely through appraisal. The two publics we examined differ not only with respect to the pragmatics of their enactment in a specific arena of water management, that is, who is the actor that enacts the public through which performative practice, directing this speech act towards which audience, and for what purpose. The two publics importantly also differ in the substance of their claims. Local environmental publics claim a deontological ethics of moral duty towards non-human nature when 
valuing the improvement of urban water quality. In contrast, the general public is characterized by an instrumentalist relation towards non-human nature that conforms to the utilitarian ethics underpinning the natural capital framework (Gómez-Baggethun et al., 2010). We summarize the pragmatic and substantive differences between publics in Table 1.

These differences extend to the kinds of value which the two publics bestow upon the natural environment (Tadaki et al., 2017), particularly whether value is embedded into social relations and malleable or wholly subjective and given (Hodgson, 1997). The way in which members of environmental stewardship groups value urban nature is embedded into their collective modes of environmental engagement (Eden, 2017). Engaging urban streams through collective practices of learning and hands-on intervention, members of local environmental stewardship groups invest their relationship with the physical landscape with non-instrumentalist values of recognition of non-human nature's intrinsic worth, responsibility towards its repair, and respect for its autonomy. When enacting a local environmental public, they argue on the basis of these values, appealing to others to examine their own evaluative regard of urban nature. In contrast to the enactment of these socially embedded and malleable values, the economic performativity of environmental valuation remains incurious about what might substantively motivate or change subjective preferences, instead recording these preferences once as price points and subsequently aggregating them as the environmental values of the general public.

Substantive differences further exist with respect to the scope of the public. Local environmental publics, or PiPs, encompass a particular social group comprising locally affected residents. In contrast, the PiG enacted through cost-benefit analysis claims to represent a social totality. Accordingly, the two publics are enacted alongside different spatialities, namely the relational spatiality of a shared environmental condition and the national territory, respectively. Finally, local environmental publics consider BGI primarily as a site of restoration and stewardship, whereas the PiG enacts the same BGI as a natural capital asset.

The enactment of a PiG responds to the institutional requirement to demonstrate the economic value of BGI, which in the context of UK public administration involves conducting cost-benefit analysis. Whereas funding and as a consequence monetary valuation were of importance to technical experts, members of environmental stewardship groups did not regard their local rivers as

Table I. Pragmatic and substantive differences between PiP and PiG.

\begin{tabular}{lll}
\hline & Public-in-Particular (PiP) & Public-in-General (PiG) \\
\hline Actor & $\begin{array}{l}\text { Members of environmental stewardship } \\
\text { groups }\end{array}$ & Technical experts \\
Practice & $\begin{array}{l}\text { Environmental engagement } \\
\text { Local authorities } \\
\text { Property developers }\end{array}$ & Economic calculation \\
& $\quad$ Residents & Funders \\
Purpose & Political demand & \\
Ethics & Deontological & Administrative appraisal \\
Value & Embedded and malleable meaning of & Utilitarian \\
& relationship & Subjectivist and fixed magnitude of \\
Scope & Affected collective & preference \\
Spatiality & Relational & Social totality \\
BGl & Site of stewardship & Territorial \\
Conservation & Restoration & Asset \\
strategy & & Natural capital \\
\hline & & \\
\hline
\end{tabular}


economic assets. This divergence would attest to the contingency of the plausibility of environmental valuation methods on social context (Fourcade, 2011).

Scholars of public participation in urban infrastructure planning emphasize the importance of recognizing the varied and non-instrumentalist ways in which actors render their infrastructural practices meaningful (Johnson et al., 2020). In our study, local residents valued water quality. In contrast, the general public of project appraisal bestowed negligible economic value on water quality. As a result, requiring that BGI investment be justified by demonstrating economic benefits effectively effaces the diversity of values animating environmental engagement and infrastructural practices. Cost-benefit analysis forecloses value pluralism, forming a barrier to an inclusive approach to hydro-social water management that 'does not seek to translate different value systems into a common metric' (Sharp, 2017: 15). Whereas the assessment of environmental outcomes lies outside of the scope of this study, our findings suggest that appraising BGI as natural capital assets potentially selects for projects with environmental objectives that have salient and readily demonstrable economic value, for example, relating to flood risk mitigation for property owners. On the flipside, the non-instrumental values on whose grounds local environmental stewardship groups advocate for improving ecological quality are at risk of being crowded out of hydrosocial water management. ${ }^{10}$

\section{Conclusion}

Our main ambition has been to shed light on the misalignment between local environmental publics and the general public of welfare economics in applied water management. Interviewing participants in BGI planning in London, we found that technical experts enact a general public and its attendant utilitarian notion of the public good for the purpose of justifying public expenditure. Interestingly for our case, this requirement to enact an exclusively economic notion of the public good frustrates attempts by water sector professionals to deliver the water quality improvement which local residents demand. While water management in England operates under putative public engagement mandates, the non-instrumental values animating local publics remain illegible to institutions requiring cost-benefit analysis for project appraisal. Current appraisal practice forms a crucial barrier to achieving value pluralism in water management. Nevertheless, the practical enactment of plural publics and their diverse values can be observed across different arenas of water management. As the state of the water environment continues to stir local publics, decisionmakers should consider which notion of the public good besides economic benefit may justify taking action.

\section{Highlights}

- Both BGI project appraisal and environmental advocacy involve performances of the public.

- Project appraisal requires performing a utilitarian public that benefits from ecosystem services such as flood risk mitigation and amenity.

- Local advocates create demand for improving water quality by stressing environmental stewardship.

- Whereas appraisal justifies public expenditure, it also renders environmental stewardship illegible to funders.

- Current appraisal practice leads to a misalignment between investment and demand and frustrates value pluralism in participatory water management. 


\section{Declaration of conflicting interests}

The authors declared no potential conflicts of interest with respect to the research, authorship and/or publication of this article.

\section{Funding}

The authors disclosed receipt of the following financial support for the research, authorship, and/or publication of this article: This work was supported by the Natural Environment Research Council (grant number NE/ S003495/1).

\section{ORCID iD}

Helge Peters (D) https://orcid.org/0000-0001-8537-2513

\section{Notes}

1. Other calculative practices capable of performing a PiG include accounting and polling (Law, 2004; Osborne and Rose, 1999).

2. The notion of environmental stewardship groups aligns with Eden's (2017) argument that people's specific relationships to the particular environments shape their knowledge and opinions.

3. On-site interviewing contributes to understanding the meaning of place (cf. De Wit, 2013).

4. In the context of local government such appraisal is seen as particularly important by the technical experts we interviewed since members of the opposition are liable to investigate whether public funds have been spent in a prudent fashion.

5. Scotland and Northern Ireland operate under different regimes.

6. Similar arguments continue to be made in favour of natural capital accounting (cf. Helm, 2015).

7. Akin to the way in which economists model society as an aggregate of individual preferences, liberal democratic theory casts the democratic public as a social totality comprised of individual actors who aim to satisfy their preferences through participation in the political process (Mouffe, 2005). Formally modelling the preferences of citizens and customers alike, the calculative work of environmental costbenefit analysis mediates between the domains of politics and economics (Barry and Slater, 2002).

8. The national scale comprises England and Wales.

9. The EU Water Framework Directive requires public participation in the management of water resources at the catchment level which, in England and Wales, has been implemented in the form of catchment partnerships including government, the private sector, and environmental stewardship groups (Defra, 2013).

10. The ecological economics literature describes a similar phenomenon of motivation crowding (Gómez-Baggethun et al., 2010).

\section{References}

Adams JGU (1971) London's third airport: From TLA to airstrip One. The Geographical Journal 137(4): 468493.

Agarwal A, S. delos Angeles M, Bhatia R, et al. (2000) Integrated Water Resources Management. Available at: https://www.gwp.org/globalassets/global/toolbox/publications/background-papers/04-integrated-waterresources-management-2000-english.pdf (accessed 29 November 2021).

Allin S (2019) Fears for wildlife on polluted Haringey river. Enfield Independent, 26 June. Available at: https:// www.enfieldindependent.co.uk/news/17731783.fears-wildlife-polluted-haringey-river/ (accessed 29 November 2021).

Atkinson G, Groom B, Hanley N, et al. (2018) Environmental valuation and benefit-cost analysis in UK policy. Journal of Benefit-Cost Analysis 9(1): 97-119.

Baird T (2017) Knowledge of practice: a multi-sited event ethnography of border security fairs in Europe and North America. Security Dialogue 48(3): 187-205. 
Barry A and Slater D (2002) Introduction: The technological economy. Economy and Society 31(2): 175-193. Barua M (2019) Animating capital: Work, commodities, circulation. Progress in Human Geography 43(4): $650-669$.

Battistoni A (2017) Bringing in the work of nature: From natural capital to hybrid labor. Political Theory 45(1): 5-31.

Bell S, Mason S and Pineo H (2019) Daylighting Moselle Brook: Understanding Risks to Public Health. London: UCL Engineering Exchange.

Berndt C and Boeckler M (2009) Geographies of circulation and exchange: Construction of markets. Progress in Human Geography 33(4): 535-551.

Bowen GA (2009) Document analysis as a qualitative research method. Qualitative Research Journal 9(2): 27-40.

Braun B and Whatmore S (2010) Political Matter: Technoscience, Democracy and Public Life. Minneapolis: Minnesota University Press.

Butler J (2010) Performative agency. Journal of Cultural Economy 3(2): 147-161.

Callon M (1998) Actor-network theory-the market test The Sociological Review 47: 181-195.

Callon M (2007) What does it mean to say that economics is performative? In: Mackenzie D, Muniesa F and Siu L (eds) Do Economists Make Markets? On the Performativity of Economics. Princeton: Princeton University Press, pp. 311-357.

Carriquiry A, Sauri D and March H (2020) Community involvement in the implementation of sustainable urban drainage systems (SUDSs): The case of Bon pastor, Barcelona. Sustainability 12(20): 510.

CIWEM (2020) SuDS in 2030: Cleaner, greener towns and cities. Available at: https://www.ciwem.org/theenvironment/suds-in-2030-cleaner-greener-towns-and-cities (accessed 10 August 2021).

Cloke P, Cook I, Crang P, et al. (2004) Practising Human Geography. London: Sage.

Cronon W (1995) The trouble with wilderness: Or, getting back to the wrong nature. In: Cronon W (ed.) Uncommon Ground: Rethinking the Human Place in Nature. New York: W.W. Norton \& Co., pp. 69-90.

Defra (2013) Catchment Based Approach: Improving the Quality of our Water Environment. London: Department for Environment, Food and Rural Affairs.

Dewey J (1927) The Public and Its Problems. Chicago: The Swallow Press.

De Wit CW (2013) Interviewing for sense of place. Journal of Cultural Geography 30(1): 120-144.

Dobson J and Dempsey N (2021) Known but not done: How logics of inaction limit the benefits of urban green spaces. Landscape Research. 46: 390-402.

Doganova L, Giraudeau M and Kjellberg H, et al. (2018) Five years! have we not had enough of valuation studies by now? Valuation Studies 5(2): 83-91.

Eden S (2017) Environmental Publics. London and New York: Routledge.

Enfield Council (2013) Meridian Water Masterplan. Available at: https://new.enfield.gov.uk/services/ planning/planning-information-meridian-water-masterplan-july-2013.pdf (accessed 29 November 2021).

Enfield Council (2019) What is meridian water? Available at: https://www.meridianwater.co.uk/\#intro (accessed 2 June 2020).

Enqvist JP, Campbell LK, Stedman RC, et al. (2019) Place meanings on the urban waterfront: A typology of stewardships. Sustainability Science 14: 589-605.

Fairbrass A, Jones K, McIntosh A, et al. (2018) Green Infrastructure for London: A Review of the Evidence. Available at: https://www.ucl.ac.uk/engineering-exchange/sites/engineering-exchange/files/ucl-greeninfrastructure-for-london.pdf (accessed 29 November 2021).

Finewood MH, Matsler AM and Zivkovich J (2019) Green infrastructure and the hidden politics of urban stormwater governance in a postindustrial city. Annals of the American Association of Geographers 109(3): 909-925.

Fisher DR, Campbell LK and Svendsen ES (2012) The organisational structure of urban environmental stewardship. Environmental Politics 21(1): 26-48.

Fletcher T, Shuster W, Hunt W, et al. (2015) SUDS, LID, BMPs, WSUD and more. The evolution and application of terminology surrounding urban drainage. Urban Water Journal 12(7): 525-542.

Foster J (1997) Valuing Nature? Ethics, Economics and the Environment. London and New York: Routledge. 
Fourcade M (2011) Cents and sensibility: Economic valuation and the nature of 'nature'. American Journal of Sociology 116(6): 1721-1777.

Fox A and Alldred P (2014) New materialist social inquiry: Designs, methods and the research-assemblage. International Journal of Social Research Methodology 2014: 1-16.

Gómez-Baggethun E, de Groot R, Lomas PL, et al. (2010) The history of ecosystem services in economic theory and practice: From early notions to markets and payment schemes. Ecological Economics 69: 1209-1218.

Grove-White R (1997) The environmental 'valuation' controversy: Observations on its recent history and significance. In: Foster J (ed.) Valuing Nature? Economics, Ethics and Environment. London and New York: Routledge, pp. 21-31.

Helm D (2015) Natural Capital. Valuing the Planet. New Haven and London: Yale University Press.

Hodgson G (1997) Economics, environmental policy and the transcendence of utilitarianism. In: Foster J (ed.) Valuing Nature? Economics, Ethics and Environment. London and New York: Routledge, pp. 48-66.

Horton B, Digman C, Ashley R, et al. (2019) B£ST Guidance - Guidance to Assess the Benefits of Blue and Green Infrastructure Using B£ST London: CIRIA.

Horwood K (2011) Green infrastructure: Reconciling urban green space and regional economic development: Lessons learnt from experience in england's north-west region. Local Environment 16(10): 963-975.

Johnson C, Bell S, Borrion A, et al. (2020) Working with infrastructural communities: A material participation approach to urban retrofit. Science, Technology, \& Human Values. 46(2): 320-345.

Jørgensen D (2015) Rethinking rewilding. Geoforum; Journal of Physical, Human, and Regional Geosciences 65: 482-488.

Lane SN, Landström C and Whatmore SJ (2011) Imagining flood futures : Risk assessment and management in practice. Philosophical Transactions of the Royal Society A 369: 1784-1806.

Laville S (2020) Shocking state of English rivers revealed as all of them fail pollution tests. The Guardian, 17 September. Available at: https://www.theguardian.com/environment/2020/sep/17/rivers-in-england-failpollution-tests-due-to-sewage-and-chemicals (accessed 29 November 2021).

Law J (2004) After Method. Mess in Social Science Research. London and New York: Routledge.

Linton J (2014) Modern water and its discontents: A history of hydrosocial renewal. Wiley Interdisciplinary Reviews: Water 1(1): 111-120.

Lorimer J, Sandom C, Jepson P, et al. (2015) Rewilding: Science, practice, and politics. Annual Review of Environment and Resources 40(1): 39-62.

Mackenzie D (2006) An Engine, not a Camera. How Financial Models Shape Markets. Cambridge, Mass.: MIT Press.

Mackenzie D (2009) Material Markets. How Economic Agents Are Constructed. Oxford: Oxford University Press.

Marcus G (1995) Ethnography in/of the world system: The emergence of multi-sited ethnography. Annual Review of Anthropology 24(1): 95-177.

Marres N (2007) The issues deserve more credit. Social Studies of Science 37(5): 759-780.

Mazzucato M, Kattel R, Albala S, et al. (2020) Alternative policy evaluation frameworks and tools. BEIS Research Paper Number 2020/44. Available at: https://www.ucl.ac.uk/bartlett/public-purpose/ publications/2020/nov/alternative-policy-evaluation-frameworks-and-tools (accessed 29 November 2021).

Metcalfe PJ, Baker W, Andrews K, et al. (2012) An assessment of the nonmarket benefits of the water framework directive for households in england and wales. Water Resources Research 48(3): W03526.

Michael M (2009) Publics performing publics: Of PiGs, PiPs and politics. Public Understanding of Science 18(5): 617-631.

Mouffe C (2005) On the Political. Abingdon: Routledge.

Muniesa F, Doganova L, Ortiz H, et al. (2017) Capitalization. A Cultural Guide. Paris: Presses des Mines.

Nost E (2015) Performing nature's value: Software and the making of oregon's ecosystem services markets. Environment and Planning A: Economy and Space 47(12): 2573-2590.

Noy C (2008) Sampling knowledge: The hermeneutics of snowball sampling in qualitative research. International Journal of Social Research Methodology 11(4): 327-344. 
Ofwat (2016) Ofwat's customer engagement policy statement and expectations for PR19. Available at: https:// www.ofwat.gov.uk/wp-content/uploads/2015/12/pap_pos20160525w2020custpdf (accessed 11 February 2021).

Osborne T and Rose N (1999) Do the social sciences create phenomena?: The example of public opinion research. The British Journal of Sociology 50(3): 367-396.

Palmer R and Haigh N (2013) Updating the National Water Environment Benefit Survey Values: summary of the peer review. Bristol: Environment Agency.

Pearce D (1998) Cost-benefit analyses and environmental policy. Oxford Review of Economic Policy 14(4): 84-100.

Pecanha Enqvist J, West S, Masterson V, et al. (2018) Stewardship as a boundary object for sustainability research: Linking care, knowledge and agency. Landscape and Urban Planning 179: 17-37.

Pellandini-Simanyi L (2016) Non-marketizing agents in the study of markets : Competing legacies of performativity and actor- network-theory in the marketization research program. Journal of Cultural Economy 9(9): 570-586.

Porter TM (1995) Trust in Numbers. The Pursuit of Objectivity in Science and Public Life. Princeton: Princeton University Press.

Prior J and Ward KJ (2016) Rethinking rewilding: A response to jørgensen. Geoforum; Journal of Physical, Human, and Regional Geosciences 69: 132-135.

Robertson MM (2006) The nature that capital can see: Science, state, and market in the commodification of ecosystem services. Environment and Planning D: Society and Space 24: 367-388.

Salvidge R (2020) DEFRA On the defensive over raw sewage pollution. Available at: https://www.endsreport. com/article/1698800/defra-defensive-raw-sewage-pollution (accessed 11 February 2021).

Saward M (2006) The representative claim. Contemporary Political Theory 5(3): 297-318.

Sen A (2000) The discipline of cost-benefit analysis. Journal of Legal Studies 29(S2): 931-952.

Shaffer P (2020) Making B£ST better (April 2020). Available at: https://www.youtube.com/playlist?list= PLinYZSz1gzVVFUF4z8MGEMDs5vFeVN1m1 (accessed 2 June 2020).

Sharp L (2017) Reconnecting People and Water. Public Engagement Amnd Sustainable Urban Water Management. London and New York: Routledge.

Staeheli LA, Mitchell D and Nagel CR (2009) Making publics: Immigrants, regimes of publicity and entry to 'The public'. Environment and Planning D: Society and Space 27(4): 633-648.

Sunstein CR (2005) Cost-benefit analysis and the environment. Ethics 115(2): 351-385.

SusDrain (2020a) B£ST (benefits estimation tool). Available at: https://www.susdrain.org/resources/besthtml (accessed 2 June 2020).

SusDrain (2020b) Benefits of SuDS. Available at: https://www.susdrain.org/delivering-suds/using-suds/ benefits-of-suds/SuDS-benefits.html (accessed 2 June 2020).

Tadaki M, Sinner J and Chan KMA (2017) Making sense of environmental values: A typology of concepts. Ecology and Society 22(1): 7.

Warner M (2002) Publics and counter-publics. Public Culture 14(1): 49-90.

Webb D, Smith C, Town B, et al. (2020) River Restoration in London: A 20 Year Review. Available at https:// www.thames21.org.uk/wp-content/uploads/2020/10/LRW-River-restoration-report-Final.pdf (accessed 29 November 2021).

Webster B (2020) Every river and lake in England fails pollution test The Times, 18 September. Available at: https://www.thetimes.co.uk/article/every-river-and-lake-in-england-fails-pollution-test-0ln58q0fg (accessed 29 November 2021).

Wild TC, Bernet JF, Westling EL, et al. (2011) Deculverting: Reviewing the evidence on the 'daylighting' and restoration of culverted rivers. Water and Environment Journal 25(3): 412-421.

Willems JJ, Kenyon A V., Sharp L, et al. (2021) How actors are (dis)integrating policy agendas for multifunctional blue and green infrastructure projects on the ground. Journal of Environmental Policy \& Planning 23(1): 84-96.

Wynne B (1996) Misunderstood misunderstanding: Social identities and public uptake of science. In: Irwin A and Wynne B (eds) The Public Reconstruction of Science and Technology. Cambridge: Cambridge University Press, pp. 19-46. 